\title{
Reducing the consumption of personal protective equipment by setting up a multifunctional sampling station in the emergency department to screen for COVID-19 infection in Taiwan
}

Po-Ting Lin', Ting-Yuan Ni ${ }^{1}$, Tren-Yi Chen ${ }^{1}$, Chih-Pei Su ${ }^{1,2}$, Hsiao-Fen Sun ${ }^{2}$, Mu-Kuan Chen ${ }^{3,4}$, Chu-Chung Chou ${ }^{1,4,5}$, Po-Yu Wang ${ }^{6}$ and Yan-Ren Lin ${ }^{1,4,5^{*}}$ (i)

\begin{abstract}
In Taiwan, high-risk patients have been identified and tested for preventing community spread of COVID-19. Most sample collection was performed in emergency departments (EDs). Traditional sample collection requires substantial personal protective equipment (PPE), healthcare professionals, sanitation workers, and isolation space. To solve this problem, we established a multifunctional sample collection station (MSCS) for COVID-19 testing in front of our ED. The station is composed of a thick and clear acrylic board $(2 \mathrm{~cm})$, which completely separates the patient and medical personnel. Three pairs of gloves (length, $45 \mathrm{~cm}$ ) are attached and fixed on the outside wall of the MSCS. The gloves are used to conduct sampling of throat/nasal swabs, sputum, and blood from patients. The gap between the board and the building is only $0.2 \mathrm{~cm}$ (sealed with silicone sealant). ED personnel communicate with patients using a small two-way broadcast system. Medical waste is put in specific trashcans installed in the table outside the MSCS. With full physical protection, the personnel conducting the sampling procedure need to wear only their N95 mask and gloves. After we activated the station, our PPE, sampling time, and sanitization resources were considerably conserved during the 4-week observation period. The MSCS obviously saved time and PPE. It elevated the efficiency and capacity of the ED for handling potential community infections of COVID-19.
\end{abstract}

Keywords: Personal protective equipment (PPE), Multifunctional sampling station, COVID-19, Emergency department

\footnotetext{
* Correspondence: H6213.lac@gmail.com

${ }^{1}$ Department of Emergency and Critical Care Medicine, Changhua Christian Hospital, Changhua, Taiwan

${ }^{4}$ School of Medicine, Chung Shan Medical University, Taichung, Taiwan

Full list of author information is available at the end of the article
}

(c) The Author(s). 2020 Open Access This article is licensed under a Creative Commons Attribution 4.0 International License, which permits use, sharing, adaptation, distribution and reproduction in any medium or format, as long as you give appropriate credit to the original author(s) and the source, provide a link to the Creative Commons licence, and indicate if changes were made. The images or other third party material in this article are included in the article's Creative Commons licence, unless indicated otherwise in a credit line to the material. If material is not included in the article's Creative Commons licence and your intended use is not permitted by statutory regulation or exceeds the permitted use, you will need to obtain permission directly from the copyright holder. To view a copy of this licence, visit http://creativecommons.org/licenses/by/4.0/ The Creative Commons Public Domain Dedication waiver (http://creativecommons.org/publicdomain/zero/1.0/) applies to the data made available in this article, unless otherwise stated in a credit line to the data. 
Dear Editor,

The outbreak of COVID-19 has devastated the community and health care facilities [1]. Nationwide extensive screening of potential COVID-19 patients might be beneficial for early identification, treatment, and the development of an isolation policy [2]. However, for some countries that are facing potential community infections and are not truly in the epidemic stage, extensive screening might rapidly consume the current personal protective equipment (PPE) and hospital capacity resources and may even result in resource insufficiency in the subsequent epidemic stage [3]. Therefore, tracing and identification of high-risk patients, especially those with positive travel, occupation, contact, and cluster (TOCC) histories, would be very useful before the epidemic stage. More importantly, rapid sample collection and examination without much PPE or hospital capacity consumption would maintain the normal functioning of emergency departments (EDs) and even the whole health care system.

In Taiwan, high-risk patients have been identified and tested (by the recommendation of the Taiwan CDC) for preventing potential COVID-19 community spread. Most of the sample collection was performed in EDs. Traditional methods for sample collection require substantial PPE, healthcare professionals, sanitation workers, and isolation space. These methods are also very time consuming, requiring wearing and removing the PPE with repeated sampling and sanitization. To solve this problem, we established a multifunctional sample collection station (MSCS) for COVID-19 testing in front of our ED. This station is composed of a thick and clear acrylic board that completely separates the patient and medical personnel. Detailed information regarding the measurements is provided in Fig. 1. Three pairs of gloves (length, $45 \mathrm{~cm}$ ) are attached and fixed on the outside wall of the MSCS. The gloves are used to conduct sampling of throat/nasal swabs, sputum, and blood from patients. The thickness of the acrylic board on the MSCS is $2 \mathrm{~cm}$. The gap between the board and building is only $0.2 \mathrm{~cm}$ (sealed with silicone sealant). ED personnel communicate with patients using a small two-way broadcast system (with fixed microphones and speakers on the wall). Medical waste (including alcohol-soaked cotton and tongue depressor) is placed in specific trashcans (15 $\mathrm{cm}^{2}$, depth $20 \mathrm{~cm}$ ), which are installed in the table outside the MSCS. With full physical protection, the personnel who conduct the sampling procedure need to wear only their N95 mask and gloves (Fig. 2).

Each ED patient rapidly received outdoor body temperature measurements and TOCC examinations conducted by machines and triage counter personnel. If they were identified as having a high/moderate

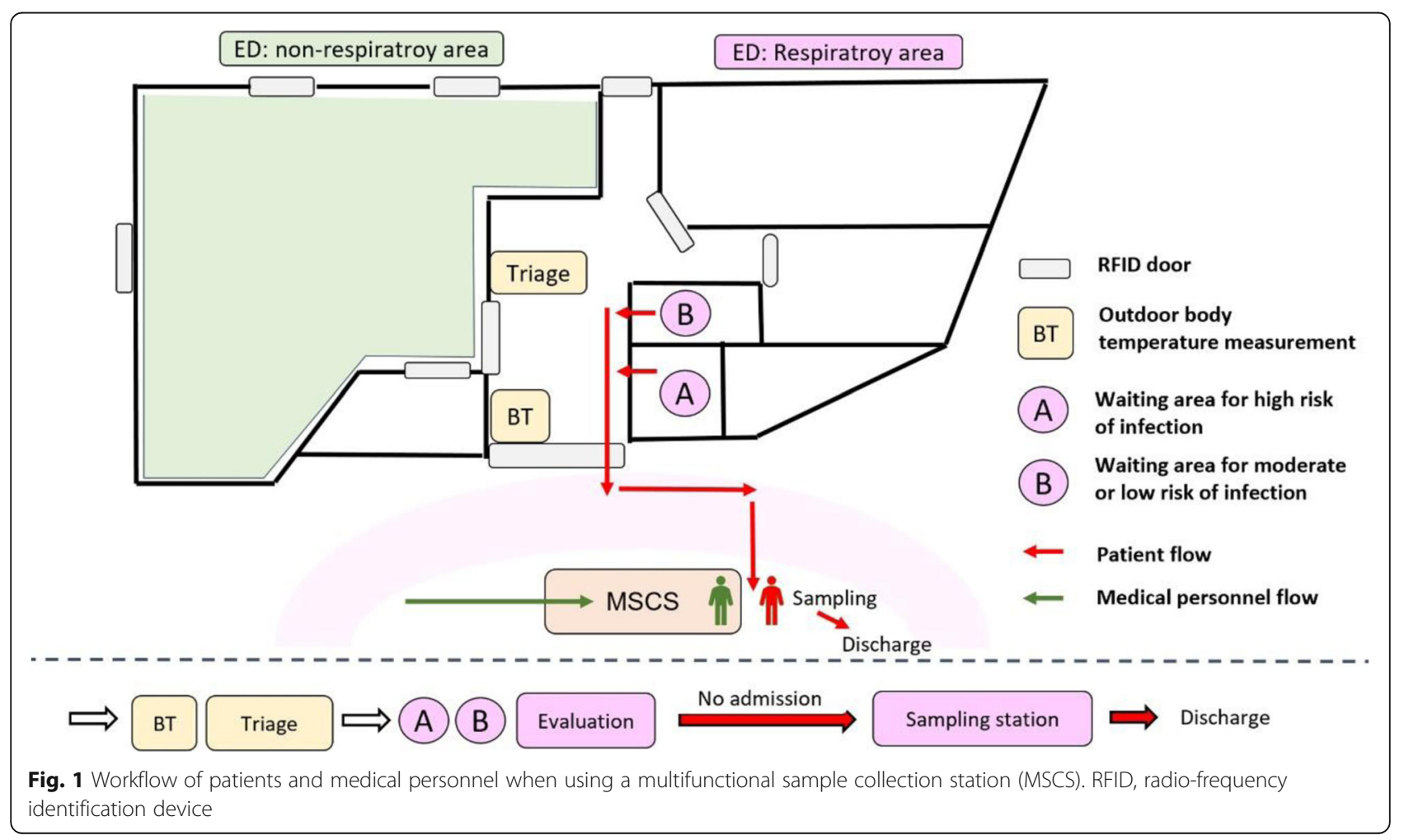




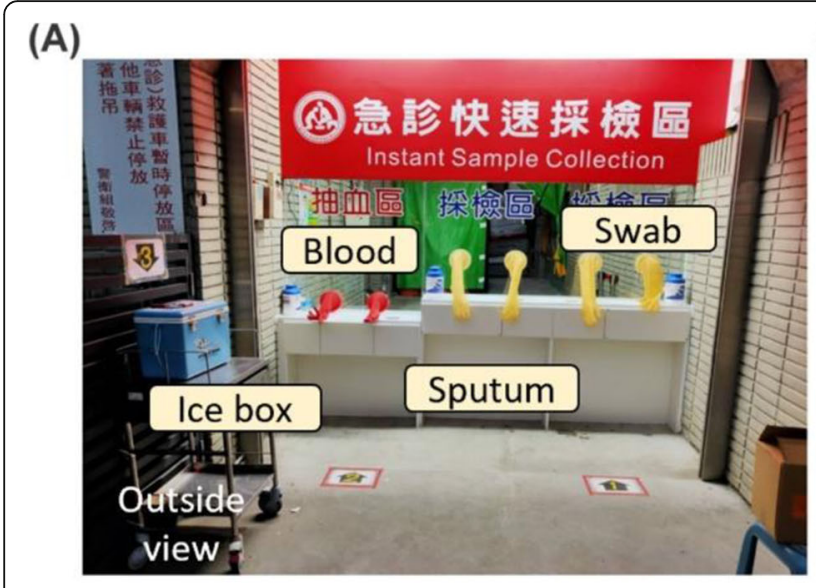

(B)

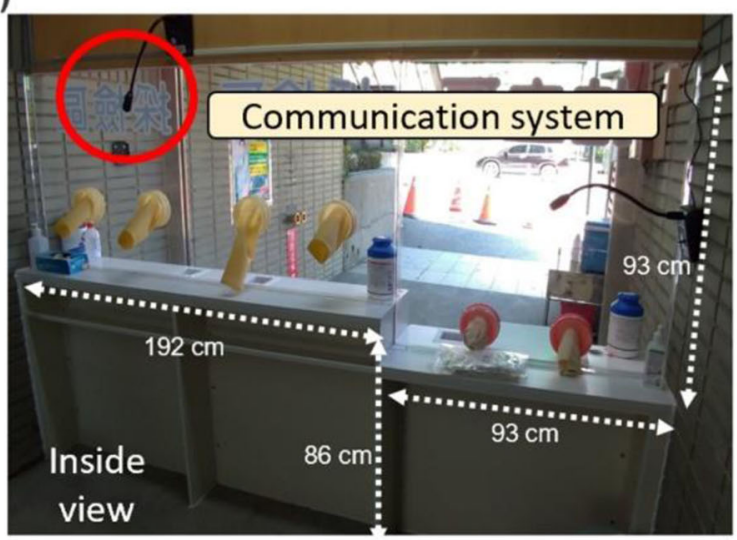

(C)
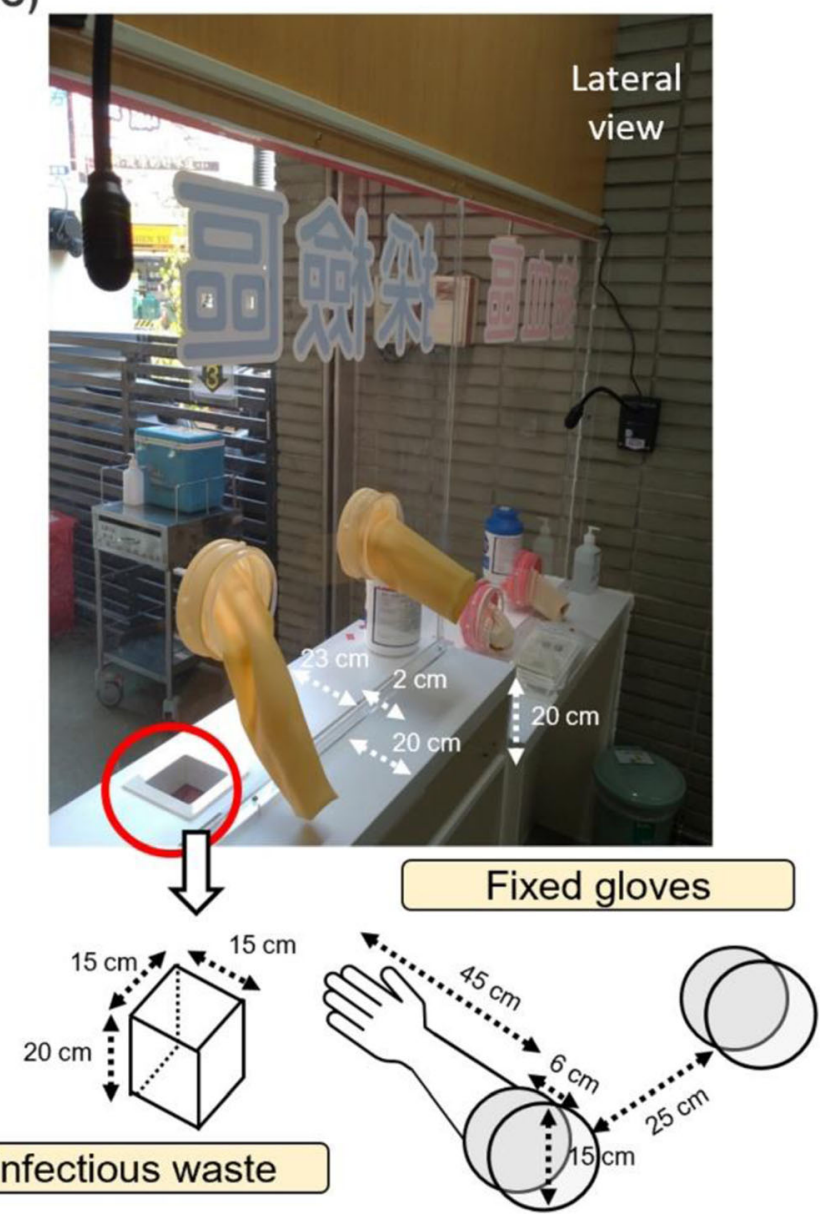

Fig. 2 a Outside, $\mathbf{b}$ inside, and $\mathbf{c}$ lateral views of the multifunctional sample collection station (MSCS). Before sampling, each patient would have their personal bag (including a syringe, alcohol-soaked cotton, a swab, gloves, a tongue depressor, and a sputum collection bottle). After sampling, they put their samples in the ice box by themselves. This station serves only one patient at a time

Table 1 Comparing the differences between traditional sampling and the multifunctional sample collection station (MSCS) during the 4-week observation period

\begin{tabular}{llll}
\hline Variables & $\begin{array}{l}\text { Traditional } \\
\text { (the first } \\
\text { two weeks) }\end{array}$ & $\begin{array}{l}\text { MSCS } \\
\text { (the last } \\
\text { two weeks) }\end{array}$ & Unit \\
\hline $\begin{array}{l}\text { The number of PPE } \\
\text { used for sampling (median) }\end{array}$ & 24 & 0 & Per day \\
$\begin{array}{l}\text { Time for suiting up and } \\
\text { removal (minutes, median) }\end{array}$ & 21 & 1 & Per patient \\
$\begin{array}{l}\text { Time for sample collection } \\
\text { (minutes, median) }\end{array}$ & 5 & 2 & Per patient \\
$\begin{array}{l}\text { Time for sanitization } \\
\text { (minutes, median) }\end{array}$ & 35 & 10 & Per patient \\
\hline
\end{tabular}

risk of COVID-19 infection, they received a quick evaluation in separate risk-associated waiting areas [4]. After initial evaluation of a chest image, virus testing for COVID-19 was performed in the MSCS (including throat/nasal swab, sputum collection, blood testing for antibody). This station served only one patient at a time (reducing the risk of crossinfection). Once the patients completed the tests, they could be discharged directly from station and await their reports at home.

After we activated the station, our PPE, sampling time, and sanitization resources were considerably conserved during the 4-week observation period. A comparison between traditional sampling (in a single negative-pressure isolation room) and using the MSCS (outside of the ED) is shown in Table 1. In conclusion, the MSCS considerably saved time and PPE. It elevated the efficiency and capacity of the ED when handling potential community infections of COVID-19. 


\section{Acknowledgements}

None.

\section{Authors' contributions}

Po-Ting Lin and Yan-Ren Lin conceptualized and designed the study. PoTing Lin and Ting-Yuan Ni helped draft the manuscript. Tren-Yi Chen, ChihPei Su, and Hsiao-Fen Sun collected the data and prepared the table and figures. Mu-Kuan Chen, Chu-Chung Chou, and Po-Yu Wang reviewed and provided conceptual advice for the manuscript. Yan-Ren Lin and Mu-Kuan Chen revised the manuscript. The authors read and approved the final manuscript.

\section{Funding}

None.

\section{Availability of data and materials}

Not applicable.

\section{Ethics approval and consent to participate}

Institutional Review Board of Changhua Christian Hospital permission

number 200409.

\section{Consent for publication}

Not applicable.

\section{Competing interests}

None.

\section{Author details}

'Department of Emergency and Critical Care Medicine, Changhua Christian Hospital, Changhua, Taiwan. ${ }^{2}$ Department of Nursing, Changhua Christian Hospital, Changhua, Taiwan. ${ }^{3}$ Department of Otorhinolaryngology, Head and Neck Surgery, Changhua Christian Hospital, Changhua, Taiwan. ${ }^{4}$ School of Medicine, Chung Shan Medical University, Taichung, Taiwan. ${ }^{5}$ School of Medicine, Kaohsiung Medical University, Kaohsiung, Taiwan. ${ }^{6}$ Department of Pediatric Emergency, Changhua Christian Children's Hospital, Changhua, Taiwan.

Received: 1 July 2020 Accepted: 22 July 2020

Published online: 30 July 2020

References

1. Mareiniss DP. The impending storm: COVID-19, pandemics and our overwhelmed emergency departments. Am J Emerg Med. 2020 Mar 23. pii: S0735-6757(20)30175-3. doi: https://doi.org/10.1016/.jajem.2020.03.033.

2. World Health Organization. Home care for patients with suspected novel coronavirus (nCoV) infection presenting with mild symptoms and management of contacts. WHO reference number: WHO/nCov/IPC/ HomeCare/2020.3. Published February 4, 2020. Accessed February 24, 2020

3. Hick JL, Biddinger PD. Novel coronavirus and old lessons - preparing the health system for the pandemic. N Engl J Med. 2020 Mar 25. https://doi.org/ 10.1056/NEJMp2005118.

4. Chen TY, Lai HW, Hou IL, Lin CH, Chen MK, Chou CC, Lin YR. Buffer areas in emergency department to handle potential COVID-19 community infection in Taiwan. Travel Med Infect Dis. 2020 Mar;20:101635. https://doi.org/10. 1016/j.tmaid.2020.101635.

\section{Publisher's Note}

Springer Nature remains neutral with regard to jurisdictional claims in published maps and institutional affiliations.

Ready to submit your research? Choose BMC and benefit from:

- fast, convenient online submission

- thorough peer review by experienced researchers in your field

- rapid publication on acceptance

- support for research data, including large and complex data types

- gold Open Access which fosters wider collaboration and increased citations

- maximum visibility for your research: over $100 \mathrm{M}$ website views per year

At BMC, research is always in progress.

Learn more biomedcentral.com/submissions 